\title{
Exposure profile of mercury, lead, cadmium, arsenic, antimony, copper, selenium and zinc in maternal blood, cord blood and placenta: the Tohoku Study of Child Development in Japan
}

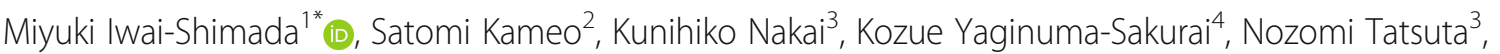 \\ Naoyuki Kurokawa ${ }^{5}$, Shoji F. Nakayama ${ }^{1}$ and Hiroshi Satoh ${ }^{6}$
}

\begin{abstract}
Background: The effects of prenatal exposure to toxic elements on birth outcomes and child development have been an area of concern. This study aimed to assess the profile of prenatal exposure to toxic elements, arsenic (As), bismuth (Bi), cadmium $(\mathrm{Cd})$, mercury (total mercury $(\mathrm{THg})$, methylmercury $(\mathrm{MHg})$, inorganic mercury $(\mathrm{IHg})$ ), lead $(\mathrm{Pb})$, antimony (Sb) and tin (Sn), and essential trace elements, copper (Cu), selenium (Se) and zinc (Zn), using the maternal blood, cord blood and placenta in the Tohoku Study of Child Development of Japan ( $N=594-650)$.

Methods: Inductively coupled plasma mass spectrometry was used to determine the concentrations of these elements (except mercury). Levels of $\mathrm{THg}$ and $\mathrm{MeHg}$ were measured using cold vapour atomic absorption spectrophotometry and a gas chromatograph-electron capture detector, respectively.

Results: Median concentrations (25th-75th) of As, Cd, Pb, Sb, Sn and THg in the maternal blood were 4.06 (2.68-6.81), $1.18(0.74-1.79), 10.8(8.65-13.5), 0.2(0.06-0.40)$ and $0.2(0.1-0.38) \mathrm{ng} \mathrm{mL}^{-1}$ and $5.42(3.89-7.59) \mathrm{ng} \mathrm{g}^{-1}$, respectively. Median concentrations (25th-75th) of As, Cd, Pb, Sb, Sn and THg in the cord blood were 3.68 (2.58-5.25), 0.53 (0.10-1. 25), 9.89 (8.02-12.5), $0.39(0.06-0.92)$ and $0.2(0.2-0.38) \mathrm{ng} \mathrm{mL}^{-1}$ and $9.96(7.05-13.8) \mathrm{ng} \mathrm{g}^{-1}$, respectively.

Conclusions: $\mathrm{THg}$ and Sb levels in the cord blood were twofold higher than those in the maternal blood. Cord blood to maternal blood ratios for As, Cd and Sb widely varied between individuals. To understand the effects of prenatal exposure, further research regarding the variations of placental transfer of elements is necessary.
\end{abstract}

Keywords: Cord blood, Placenta, Maternal blood, Trace element, Metal

\section{Background}

Humans have experienced various adverse effects from environmental contaminants, especially toxic elements such as arsenic (As), cadmium $(\mathrm{Cd})$, mercury $(\mathrm{Hg})$ and lead $(\mathrm{Pb})$, which are detrimental to human health. In addition, these elements are ranked among the ten most toxic substances by the Agency for Toxic Substances and Disease Registry [1]. Although individuals in

\footnotetext{
* Correspondence: iwai.miyuki@nies.go.jp

${ }^{1}$ Centre for Health and Environmental Risk Research, National Institute for

Environmental Studies, Tsukuba, Ibaraki, Japan

Full list of author information is available at the end of the article
}

developed countries may no longer suffer from severe poisoning caused by exposure or overexposure to these elements, chronic and low exposure remains a health hazard. A developing foetus, in particular, is highly vulnerable to the toxic effects of these elements $[2,3]$.

Maternal exposure to these toxic elements may happen through diet, air, drinking water, house dust and tobacco use and/or passive smoking [3]. Mothers may also be exposed to these elements in the workplace. Inorganic $\mathrm{Hg}$ $(\mathrm{IHg})$ is biologically transformed in the aquatic environment from its inorganic form into methylmercury $(\mathrm{MeHg})$, a toxic form of the element. Consequently, 
humans who consume fish and other seafood are potentially exposed to $\mathrm{MeHg}$, and this exposure increases the risk of neurodevelopmental disorders [2, 4, 5]. Exposure to $\mathrm{Pb}$ can cause spontaneous abortions [6] and can lead to reduced birth weight, gestational hypertension, congenital malformations [7] and impaired neurodevelopment [8]. Even low levels of in utero exposure to $\mathrm{Pb}$ may result in adverse birth outcomes and neurodevelopmental effects such as reduced intelligence and symptoms pertaining to attention-deficit/hyperactivity disorder (ADHD) [9, 10]. Exposure to $\mathrm{Cd}$ is also potentially hazardous to foetal health. However, the placenta acts as a barrier to $\mathrm{Cd}$ exposure for the foetus by increasing metallothionein expression [11]. Nonetheless, Cd is found in the cord blood, and this exposure has been associated with decreased birth weight [12]. Prenatal As exposure is associated with adverse birth outcomes [13], and it can adversely affect the health of adults [14] and can lead to increased mortality and an increased risk of lung and liver cancers $[15,16]$. Copper $(\mathrm{Cu})$, zinc $(\mathrm{Zn})$ and selenium $(\mathrm{Se})$ are essential trace elements and involved in numerous biochemical processes that support life [17]. Bismuth (Bi), a minor metal, has been used in pharmaceuticals and cosmetics. Bi is also found in low concentrations in biological and environmental samples, including blood, urine, food and water $[18,19]$. Antimony $(\mathrm{Sb})$ is another minor metal and used in pharmaceuticals. $\mathrm{Sb}$ is usually present in the environment in very low concentrations [20]. Volonakis et al. [21] reported the development of new Pb-free materials (e.g. $\mathrm{Pb}$-free inorganic halide double perovskites) based on $\mathrm{Bi}$ or Sb. New materials made with $\mathrm{Bi}$ and $\mathrm{Sb}$ have been used as a substitute for lead. According to a review of the literature, the available data regarding the effects of exposure to $\mathrm{Sb}$ and $\mathrm{Bi}$ on general and vulnerable populations is insufficient.

The effects of prenatal exposure to toxic elements have been reported extensively. Consequently, more attention has been paid to the effects of toxic elements on pregnancy outcomes and/or adverse developmental effects at levels lower than current international guidelines [22-24]. The extent of prenatal exposure to environmental contaminants has been assessed primarily using cord and/or maternal blood samples [25-27]. However, few reports have assessed the relationship between ten elements by using the complete data of the maternal blood, cord blood and placenta in general populations of Japan.

In this study, we presented a novel examination of maternal exposure to multiple elements [i.e. $\mathrm{Cd}, \mathrm{Hg}$ (total $\mathrm{Hg}$ [THg], $\mathrm{MeHg}$ and $\mathrm{IHg}$ ), $\mathrm{Pb}, \mathrm{As}$ (total $\mathrm{As}$ ), $\mathrm{Sb}, \mathrm{Bi}, \mathrm{Sn}, \mathrm{Cu}, \mathrm{Zn}$ and $\mathrm{Se}]$ and transplacental transfer of these elements from the mother to the foetus in Japan. We investigated these elements by considering the environmental health effects, the possibility of minor metal exposures and the confounding aspect of trace elements. The aim of this study was to (1) evaluate the prenatal exposure to toxic and essential trace elements using the maternal blood and cord blood by focusing on $\mathrm{As}, \mathrm{Bi}, \mathrm{Cu}, \mathrm{Cd}, \mathrm{Hg}$ ( $\mathrm{THg}, \mathrm{MeHg}$ and $\mathrm{IHg}$ ), $\mathrm{Pb}$, Sb, Se, $\mathrm{Sn}$ and $\mathrm{Zn}$ and (2) assess the placental transfer of the selected elements.

\section{Methods}

\section{Study design, subjects and sampling}

We performed a birth cohort study called the Tohoku Study of Child Development (TSCD) in the northeastern area of Japan. The Japanese refer to this area as the 'Tohoku region'. This study was conducted in an urban area (registered between 2001 and 2003) and a coastal area (registered between 2002 and 2006). The details and protocols of this study have been described elsewhere [28]. In summary, 687 pregnant Japanese women were enrolled for participation in this study, and we obtained written informed consent from all participants before beginning their part in the study [28]. We followed up on the mothers and their resulting infant pairs, and the infants' development was examined regarding prenatal exposures to environmental contaminants, such as $\mathrm{MeHg}, \mathrm{Pb}$ and polychlorinated biphenyls (PCBs) [29-32]. This article analysed the samples from the urban area (Additional file 1: Figure S1).

In the urban area, the maternal blood was collected at 28 weeks of pregnancy using venepuncture into a tube containing heparin. Similarly, the cord blood was collected from the umbilical cord vein immediately after delivery; the placentas were also collected during delivery. A representative sample was collected from the lower parts of the root of the cord tissue because the placenta is a large organ and a heterogeneous mixture of placental cells and decidual tissues containing the maternal and foetal blood [33]. Acharya et al. indicated that approximately $40 \%$ of the blood is contained in the placenta. The representative sample was processed by homogenisation before use. The blood and placenta samples were stored at $-80^{\circ} \mathrm{C}$ until the analyses.

\section{Analytical methods Determination of mercury}

Cold vapour atomic absorption spectrometry (CVAAS; HG-201, Sanso Seisakusho Co. Ltd., Tokyo, Japan) was used to measure the THg level in the whole blood and placenta. The analytical CVAAS method has been completely described elsewhere [34, 35]. A gas chromatograph-electron capture detector was used to measure the $\mathrm{MeHg}$ level in the blood samples (GC-ECD) [34, 36]. The concentrations of $\mathrm{IHg}$ were calculated by subtracting $\mathrm{MeHg}$ levels from $\mathrm{THg}$ concentrations.

\section{Determination of other toxic metals and essential trace elements}

We determined the levels of toxic elements $\mathrm{As}, \mathrm{Bi}, \mathrm{Cd}$, $\mathrm{Pb}, \mathrm{Sb}$ and $\mathrm{Sn}$ and the levels of essential trace elements 
$\mathrm{Cu}, \mathrm{Zn}$ and Se using inductively coupled plasma mass spectrometry (ICP-MS; 7500c, Agilent Technologies, Inc. CA, USA, Table 1). A sample (approximately $0.5 \mathrm{~mL}$ of the blood and approximately $0.2 \mathrm{~g}$ of the placenta) was weighed and placed at the bottom of a fluororesin airtight sample container. Appropriately $1 \mathrm{~mL}$ of nitric acid $\left(\mathrm{HNO}_{3}\right)$ was added to the blood, whereas $2 \mathrm{~mL}$ of $\mathrm{HNO}_{3}$ and $2 \mathrm{~mL}$ of distilled water were added to the placenta. Pressure decomposition was conducted using a microwave at $600 \mathrm{~W}$ for $30 \mathrm{~min}$ (MDS-2000, CEM Corporation, NC, USA). These analyses were performed by IDEA Consultants, Inc. (Tokyo, Japan).

\section{Analytical quality control}

We used a reference material (Seronorm Trace Elements Whole Blood Level 2 and 3 prepared by the SERO AS, Norway) for quality control (Additional file 1: Tables S1 and S2). Moreover, the data quality for $\mathrm{THg}, \mathrm{Cd}$ and $\mathrm{Pb}$ concentrations was verified using external quality assurance programmes (Additional file 1: Table S2). The quality of $\mathrm{MeHg}$ analyses was confirmed in two laboratories by IDEA Consultants, Inc. and International Mercury Laboratory, Co., Ltd. Both laboratories used the same whole blood samples $(N=5$, Pearson's $r=0.999, P<0.001$, Additional file 1: Figure S2). The limits of detection (LODs) for each analyte were calculated according to Currie's method [37].

\section{Data analysis}

The concentration levels of the elements in the maternal blood, cord blood and placenta were assessed for normality using the Shapiro-Wilk test. Their concentrations

Table 1 Instrumental setting for ICP-MS

\begin{tabular}{ll}
\hline Instrument & Agilent 7500 c \\
\hline Mass monitored & Cu: 63 \\
Zn: 66 & As: 75 \\
& Se: 78 \\
& Cd: 111 \\
& Sn: 118 \\
Sb: 121 \\
Pb: 208 \\
Internal standards & Bi: 209 \\
Reaction gas & Ge: 72 \\
& Y: 89 \\
& Rh: 103 \\
& In: 115 \\
& Tl: 205 \\
& He, $\mathrm{H}_{2}$ \\
& $1.5-1.6 \mathrm{~kW}$ \\
\hline
\end{tabular}

were presented as medians, namely, 25-75 percentiles and ranges, because the distribution was skewed. We also performed Spearman's rank correlation coefficients (rho) analysis. The concentration levels of the samples were assessed by performing a nonparametric Kruskal-Wallis analysis; this was followed by a Dunn test. $P<0.05$ was considered statistically significant. The software package JMP12.0.2 (SAS Institute Inc., Cary, NC, USA) was used for statistical analysis.

\section{Results}

The toxic and trace element concentrations are summarised in Table $2(N=594-650)$. The mean gestational age (SD) and maternal age (SD) at birth were 39.5 (1.3) weeks and 31.4 (4.4) years old, respectively $(N=580$, Additional file 1: Figure S1). The mean placental weight (SD) at birth was 559 (97) g $(N=565)$. Sn and Bi levels were $44 \%$ and $7 \%$, respectively, in the maternal blood sample and $36 \%$ and $18 \%$, respectively, in the cord blood sample. Therefore, $\mathrm{Bi}$ and $\mathrm{Sn}$ concentration levels were excluded from the subsequent analysis.

Figure 1 displays simple correlations between each element in the maternal and cord blood. Values less than the LODs were also excluded. Strong correlations were observed between $\mathrm{THg}$ (and $\mathrm{MeHg}$ ) in the maternal and cord blood (Spearman's rho $=0.78$ [0.77]). Correlations for $\mathrm{Pb}, \mathrm{As}$ and $\mathrm{Se}$ in the maternal and cord blood were significant but moderate to weak (Spearman's $r h o=0.41$, 0.20 and 0.26 , respectively). No significant correlations were noted for $\mathrm{Cu}, \mathrm{Zn}$ and $\mathrm{Sb}$ in the maternal and cord blood. Spearman's correlations for the elements in the maternal blood, cord blood and placenta are shown as (Additional file 1: Table S3, $N=580$ ).

Figure 2 compares the concentrations of the toxic elements with the trace elements in the maternal blood, cord blood and placenta. Concentrations of $\mathrm{As}$ and $\mathrm{Pb}$ in the cord blood were significantly lower than those in the maternal blood and placenta. Concentrations of $\mathrm{THg}, \mathrm{Cd}, \mathrm{Zn}$ and Se in the placenta were significantly higher than those in the maternal and cord blood.

Figure 3 shows cord blood to maternal blood ratios of the toxic and trace elements. The median ratios of $\mathrm{Zn}$, $\mathrm{Cu}$ and $\mathrm{Cd}$ were approximately 0.5 , and the median ratios of $\mathrm{As}$, Se and $\mathrm{Pb}$ were approximately 1.0. By contrast, the median ratios of $\mathrm{Sb}, \mathrm{THg}$ and $\mathrm{MeHg}$ were approximately 2.0. The variations of the $\mathrm{Cu}, \mathrm{Zn}, \mathrm{Se}, \mathrm{Pb}$, $\mathrm{THg}$ and $\mathrm{MeHg}$ ratios were small [relative standard deviation (RSD), 25-55\%], whereas the variations of the $\mathrm{As}, \mathrm{Bi}, \mathrm{Cd}$ and $\mathrm{Sb}$ ratios were large (RSD, 94-450\%).

\section{Discussion}

$\mathrm{MeHg}$ and $\mathrm{THg}$ concentration levels in the cord blood showed strong associations with their concentration levels in the maternal blood, whereas $\mathrm{As}, \mathrm{Pb}$ and $\mathrm{Se}$ 
Table 2 Exposure levels of toxic and essential trace elements in the maternal blood, cord blood and placenta

\begin{tabular}{|c|c|c|c|c|c|c|c|}
\hline & Elements & $N$ & Median & 25th-75th percentile & Min & Max & $<\operatorname{LOD}^{\mathrm{b}}(\%)$ \\
\hline \multirow[t]{12}{*}{ Maternal blood $\left(\mathrm{ng} \mathrm{mL}^{-1}\right)$} & As & 649 & 4.06 & $2.68-6.81$ & $<0.30^{\mathrm{b}}$ & 17.64 & 2.3 \\
\hline & $\mathrm{Bi}$ & 649 & $0.02^{\mathrm{b}}$ & $0.02^{b}-0.02^{b}$ & $<0.02^{\mathrm{b}}$ & 2.51 & 92.6 \\
\hline & $\mathrm{Cd}$ & 649 & 1.18 & $0.74-1.79$ & $<0.10^{\mathrm{b}}$ & 11.23 & 5.4 \\
\hline & $\mathrm{Cu}$ & 649 & 1289.2 & 1155.9-1449.1 & 501.5 & 2677.5 & 0 \\
\hline & $\mathrm{Pb}$ & 649 & 10.83 & $8.65-13.50$ & 3.10 & 70.24 & 0 \\
\hline & $\mathrm{Sb}$ & 649 & 0.20 & $0.06^{\mathrm{b}}-0.40$ & $<0.06^{\mathrm{b}}$ & 7.99 & 31.4 \\
\hline & $\mathrm{Se}$ & 649 & 176.4 & $155.1-196.7$ & 93.3 & 416.3 & 0 \\
\hline & $S n$ & 649 & $0.20^{\mathrm{b}}$ & $0.20^{b}-0.38$ & $<0.20^{\mathrm{b}}$ & 7.95 & 55.6 \\
\hline & $\mathrm{THg}^{\mathrm{a}}$ & 650 & 5.42 & $3.89-7.59$ & 0.61 & 25.19 & 0 \\
\hline & $\mathrm{MeHg}^{\mathrm{a}}$ & 645 & 5.15 & $3.68-7.15$ & 0.60 & 24.99 & 0 \\
\hline & $\mathrm{Hg}^{\mathrm{a}}$ & 645 & 0.24 & $0.09-0.43$ & $<0.01$ & 1.61 & \\
\hline & $\mathrm{Zn}$ & 649 & 4769.0 & $4146.7-5417.8$ & 2707.2 & $14,416.6$ & 0 \\
\hline \multirow[t]{12}{*}{ Cord blood (ng mL ${ }^{-1}$ ) } & As & 594 & 3.68 & $2.58-5.25$ & $<0.30^{\mathrm{b}}$ & 22.41 & 0.5 \\
\hline & $\mathrm{Bi}$ & 594 & $0.02^{\mathrm{b}}$ & $0.02^{b}-0.02^{b}$ & $<0.02^{\mathrm{b}}$ & 1.87 & 82.0 \\
\hline & $\mathrm{Cd}$ & 594 & 0.53 & $0.10^{b}-1.25$ & $<0.10^{b}$ & 10.52 & 26.4 \\
\hline & $\mathrm{Cu}$ & 594 & 510.8 & $456.2-566.5$ & 243.5 & 1429.8 & 0 \\
\hline & $\mathrm{Pb}$ & 594 & 9.89 & $8.02-12.48$ & 3.66 & 61.61 & 0 \\
\hline & $\mathrm{Sb}$ & 594 & 0.39 & $0.06^{b}-0.92$ & $<0.06^{\mathrm{b}}$ & 6.40 & 28.3 \\
\hline & $\mathrm{Se}$ & 594 & 191.4 & $166.5-219.0$ & 73.9 & 376.2 & 0 \\
\hline & $S n$ & 594 & $0.20^{\mathrm{b}}$ & $0.20^{b}-0.38$ & $<0.20^{\mathrm{b}}$ & 5.23 & 63.6 \\
\hline & $\mathrm{THg}^{\mathrm{a}}$ & 601 & 9.96 & $7.05-13.80$ & 1.60 & 43.90 & 0 \\
\hline & $\mathrm{MeHg}^{\mathrm{a}}$ & 598 & 9.47 & $6.70-13.28$ & 1.52 & 43.15 & 0 \\
\hline & $\mathrm{Hg}^{\mathrm{a}}$ & 598 & 0.27 & $0.10-0.63$ & $<0.01$ & 2.43 & \\
\hline & $\mathrm{Zn}$ & 594 & 2002.9 & 1757.7-2352.2 & 1103.9 & $22,258.6$ & 0 \\
\hline \multirow[t]{10}{*}{ Placenta (ng g-wet ${ }^{-1}$ ) } & As & 617 & 4.36 & $3.26-5.93$ & 1.18 & 19.56 & 0 \\
\hline & $\mathrm{Bi}$ & 617 & $0.03^{b}$ & $0.03^{b}-0.04$ & $<0.03^{b}$ & 1.35 & 72.6 \\
\hline & $\mathrm{Cd}$ & 617 & 16.95 & $12.97-22.72$ & 3.52 & 51.49 & 0 \\
\hline & $\mathrm{Cu}$ & 617 & 706.5 & $627.1-806.5$ & 442.9 & 1419.3 & 0 \\
\hline & $\mathrm{Pb}$ & 617 & 11.21 & $7.67-15.55$ & 2.14 & 125.00 & 0 \\
\hline & $\mathrm{Sb}$ & 617 & 0.24 & $0.10^{b}-0.56$ & $<0.10^{\mathrm{b}}$ & 33.43 & 37.8 \\
\hline & $\mathrm{Se}$ & 617 & 295.3 & $265.0-331.9$ & 172.4 & 503.5 & 0 \\
\hline & $\mathrm{Sn}$ & 617 & 11.83 & $6.55-19.43$ & $<0.30^{\mathrm{b}}$ & 197.56 & 1.9 \\
\hline & $\mathrm{THg}$ & 617 & 12.60 & $9.31-16.47$ & 1.98 & 52.44 & 0 \\
\hline & $\mathrm{Zn}$ & 617 & 9101.4 & 8353.3-9917.1 & 6771.8 & $17,381.8$ & 0 \\
\hline
\end{tabular}

Copper, selenium and zinc concentrations were presented up to one decimal digit because of high concentration compared with other elemental concentrations As arsenic, Bi bismuth, $\mathrm{Cd}$ cadmium, $\mathrm{Cu}$ copper, $\mathrm{Pb}$ lead, $\mathrm{Sb}$ antimony, Se selenium, $\mathrm{Sn}$ tin, $\mathrm{TH} g$ total mercury, $\mathrm{MeHg}$ methylmercury, $\mathrm{IHg}$ inorganic mercury (IHg concentrations were calculated by subtracting $\mathrm{MeHg}$ from $\mathrm{THg}), \mathrm{Zn}$ zinc

${ }^{a} \mathrm{ng} \mathrm{g}^{-1}$

bimit of detection (LOD)

concentration levels in the cord blood showed moderate associations with their concentration levels in the maternal blood. No significant associations were observed between the concentration levels of $\mathrm{Cd}, \mathrm{Zn}, \mathrm{Cu}$ and $\mathrm{Sb}$ in the maternal and cord blood. These findings indicate that $\mathrm{Hg}$ (i.e. $\mathrm{MeHg}$ and $\mathrm{THg}$ ) concentrations in the maternal blood represent foetal exposure, whereas the others do not. Notably, even in the assessment of foetal exposure to $\mathrm{MeHg}$, the cord blood is a more useful and valid biomarker [38]. This is so because the increased $\mathrm{THg}$ concentration in the cord blood was associated with some neurobehavioural and neurophysiological deficits in children [2,38]. To assess the extent and resulting health effects of foetal exposure to $\mathrm{As}, \mathrm{Pb}, \mathrm{Cd}, \mathrm{Se}$, 


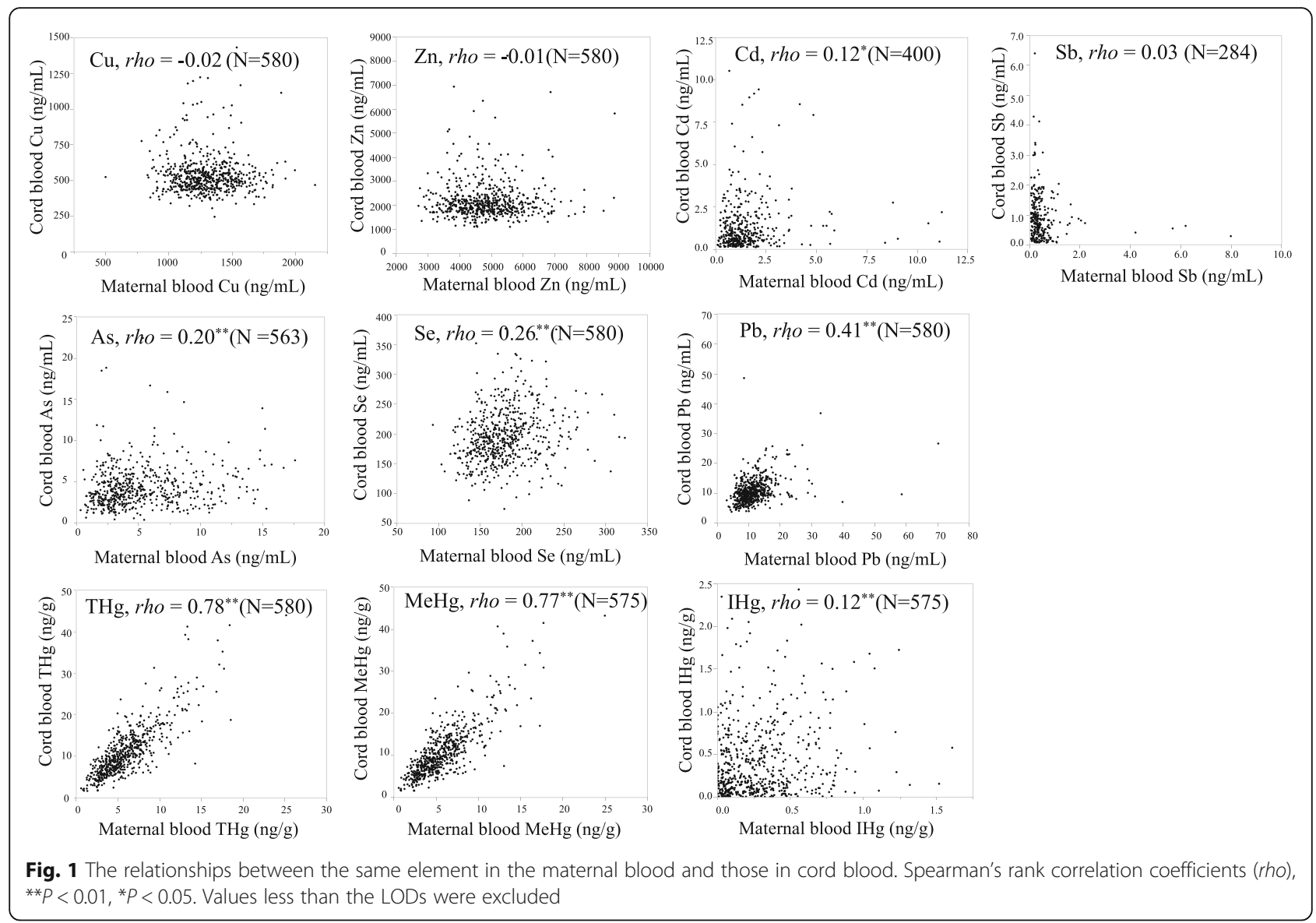

$\mathrm{Zn}, \mathrm{Cu}$ and $\mathrm{Sb}$, the use of the cord blood may be more suitable than the maternal blood (in especially, in case of no correlation between element concentrations in the maternal blood and cord blood). Maternal blood measurements have also the following some advantages: the maternal blood is easier to access, to get multiple sampling and more useful for preventive actions, including the process of setting reference values. To overcome this dilemma, foetal exposure simulation models must be developed using physiologically based pharmacokinetic (PBPK) modelling. The results of this study suggest that more information is required regarding the transplacental behaviour of these elements, such as active transportation and binding protein expressions [39, 40].

$\mathrm{MeHg}$ could be actively transported by the placenta through cysteine conjugate via the neutral amino acid carrier system [41]. Many studies have reported that $\mathrm{MeHg}$ was higher in the cord blood than in the maternal blood [42-45]. The average cord blood to maternal blood ratio of $\mathrm{MeHg}$ ranged from 0.8 to 2.8, with a mean value of 1.65 [45]. In this study, the median ratio was 1.8. Moreover, according to our review of the literature, this study may be the first to report the placental transfer of $\mathrm{Sb}$ (the median ratio was 2.0). The median cord blood to maternal blood ratios of $\mathrm{Cd}, \mathrm{Cu}$ and $\mathrm{Zn}$ were less than 1 (there was no correlation between their element concentrations in the maternal and cord blood). Metallothionein of the metal-binding protein could be induced by some metals, such as $\mathrm{Cd}, \mathrm{Cu}$ and $\mathrm{Zn}$ [46]. For a $\mathrm{Cd}$ and $\mathrm{Zn}$ interaction, the accumulation of $\mathrm{Cd}$ in the placenta reportedly induces the expression of metallothionein, which could lead to $\mathrm{Zn}$ retention in the placenta with subsequent reduced transfer to the foetus $[47,48]$. This finding indicates that metallothionein expression in the placenta plays a role in modifying the transfer of $\mathrm{Cd}, \mathrm{Cu}$ and $\mathrm{Zn}$ to the cord blood.

The median of blood $\mathrm{Sb}$ concentrations in a sample of 89 male and female German adults (median $0.6 \mu \mathrm{g} \mathrm{L}{ }^{-1}$, range < LOD-7.54 $\mu \mathrm{g} \mathrm{L}^{-1}$, [49]) was similar to the levels reported in this study, whereas these concentrations in pregnant women in Western Australia (median $1.54 \mu \mathrm{g} \mathrm{L}^{-1}$, range $0.16-7.31 \mu \mathrm{g} \mathrm{L}^{-1}$, [50]) were slightly higher in the participants of this study. Because maximum Sb levels in the participants in this study were similar to the levels noted in German adults and the pregnant women in Western Australia, we considered 


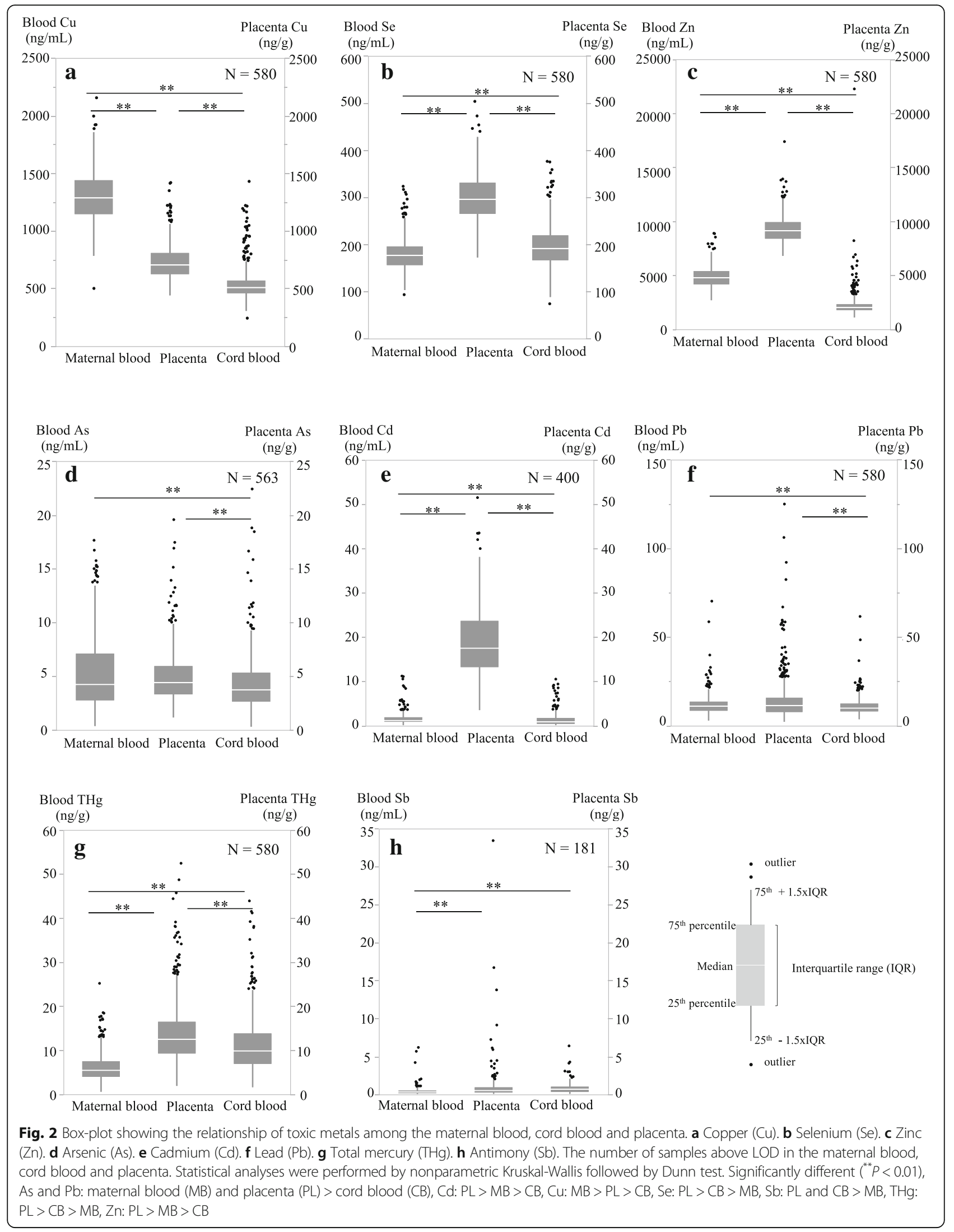




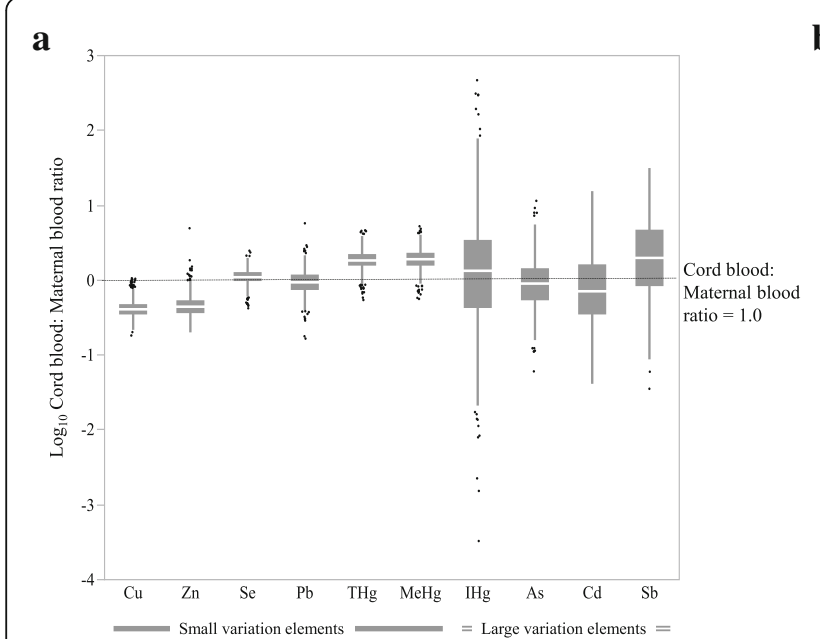

b

Fig. 3 Box-plot and table showing cord blood to maternal blood ratios of toxic and trace elements in the study population. a Cord blood to maternal blood ratios of $\mathrm{Cu}, \mathrm{Zn}, \mathrm{Se}, \mathrm{Pb}, \mathrm{THg}$ and $\mathrm{MeHg}$ were small variation and those of $\mathrm{Hg}$, As, Cd and Sb elements were large variation. $\mathbf{b}$ Table shows cord blood to maternal blood ratios of each element

that the participants in this study were under general environmental $\mathrm{Sb}$ exposure. Reports have suggested that household dust [51], soil and airborne particles [52] are contaminated with Sb. Yoshinaga et al. [53] reported that geometric mean Sb levels (SD) in house dust of Japanese residences $(N=100)$ was $10.1(2.06) \mathrm{mg} \mathrm{kg-dry}^{-1}$ and that result was two times higher levels than house dust in Canada. Further studies are necessary to evaluate the exposure source of $\mathrm{Sb}$ and the effects.

Kidney-Cd half-life was estimated between 18 and 44 years, whereas blood-Cd half-life was a few months [54, 55]. Certain studies have reported a higher accumulation of $\mathrm{Cd}$ in the placenta than in the maternal blood or cord blood because of the limited transplacental passage [56, 57]. This result could explain the comparatively no correlation between $\mathrm{Cd}$ levels in the maternal blood and cord blood ( $r=0.042$ [58], 0.25 [59], - 0.14 [42]). Compared with the placental Cd levels reported in 46 studies [60], the participants of this study are observed to have experienced moderate $\mathrm{Cd}$ exposure.

The geometric mean levels of blood $\mathrm{THg}$ were 0.678 ng $\mathrm{mL}^{-1}$ in NHANES 2013-2014 $(N=2628$, female $)$ in the United States (USA) [61]. The median levels of maternal blood THg were $0.64 \mathrm{ng} \mathrm{mL}^{-1}$ in MIREC $(N=1835)$ in Canada [62] and 2.24 $\mathrm{ng} \mathrm{mL}^{-1}$ in Taiwan $(N=145$, [63]). Our median value of $5.42 \mathrm{ng} \mathrm{g}^{-1}$ ( $5.69 \mathrm{ng} \mathrm{mL}$, adjusted for blood-specific gravity as 1.05) in the maternal blood was higher than the median values obtained from these countries. The mercury exposure of the participants in this study was lower compared with the participants in the Faroese birth cohort study and the Seychelles Child Development Study [2].

The geometric mean levels of $\mathrm{Pb}$ in the blood were $0.842 \mu \mathrm{g} \mathrm{dL}^{-1}$ in NHANES 2013-2014 ( $N=2628$, female $)$ in the USA [61] and $3.97 \mu \mathrm{g} \mathrm{dL} \mathrm{d}^{-1}$ in China $(N=1931$, [64]). The median levels of maternal blood $\mathrm{Pb}$ were $0.59 \mu \mathrm{g} \mathrm{dL}^{-1}$ in MIREC $(N=1835)$ in Canada [62]. Our median value of $1.08 \mu \mathrm{g} \mathrm{dL} \mathrm{d}^{-1}$ in the maternal blood is similar to these values, with the exception of China.

The cord blood As level in this study was similar to that obtained from the USA (child blood, [65]) and Taiwan (cord blood) and was a little higher than that from Nepal (cord blood) [66, 67]. Because we measured only total As levels in the blood, we do not have data regarding inorganic As (and the metabolites) and high toxicity (our limitation). A significant number of studies have measured total As and/or inorganic As by speciation using urine [66]. Individuals in Japan are exposed to organic As, especially arsenobetaine, the nontoxic form of As, which is typically found in seafood, especially shellfish and seaweed $[68,69]$. Notably, the positive relationship between $\mathrm{THg}$ and As (details are presented in Additional file 1: Table S3) may be a result of seafood consumption. Exposure to As is typically measured by analysing urine and blood samples [70]. To investigate the effects of inorganic As on child development, we must assess the extent of exposure to inorganic As by speciation. By doing so, we can determine the inorganic As level in the cord blood; hair and nails are also reliable indicators of long-term exposure to inorganic As [71].

\section{Elements with a small variation in cord blood to maternal blood ratios ( $\mathrm{Cu}, \mathrm{Zn}, \mathrm{Se}, \mathrm{Pb}, \mathrm{THg}$ and $\mathrm{MeHg}$ )}

The variations in cord blood to maternal blood ratios among individuals were low for $\mathrm{Cu}, \mathrm{Zn}$ and $\mathrm{Se}(\mathrm{RSD}=32$, 55 and $25 \%$, respectively). $\mathrm{Cu}, \mathrm{Zn}$ and $\mathrm{Se}$ are essential 
trace elements involved in many life-supporting biochemical processes [17]. By contrast, excess intake of these trace elements leads to disease and toxicity [17]. Notably, because $\mathrm{Cu}$ and $\mathrm{Zn}$ are highly toxic for the foetus [72],

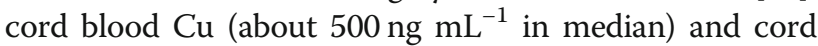
blood $\mathrm{Zn}$ (about $2000 \mathrm{ng} \mathrm{mL}^{-1}$ in median) seemed to be properly regulated in vivo (details in Fig. 2).

The variations in ratios among individuals were also low for the following toxic metals: $\mathrm{Pb}, \mathrm{THg}$ and $\mathrm{MeHg}$ ( $R S D=43,33$ and $34 \%$, respectively). It may be regulated in vivo like essential trace elements. Although $\mathrm{Pb}$ is not essential to support life, it is freely transported from the mother to the foetus through the placenta [60]. A possibility is that $\mathrm{Pb}^{2+}$ ions mimic $\mathrm{Ca}^{2+}$ ions [73] in several physiological phenomena. For example, maternal dietary calcium supplementation during pregnancy and lactation was associated with reductions in $\mathrm{Pb}$ levels in animal and human studies [74].

\section{Elements with large variations in cord blood to maternal blood ratios (As, $\mathrm{Cd}$ and $\mathrm{Sb}$ )}

The variations in cord blood to maternal ratios among individuals were high for $\mathrm{As}, \mathrm{Sb}$ and $\mathrm{Cd}(\mathrm{RSD}=94,130$ and $130 \%$, respectively), as exists in different chemical forms in the blood. The proportion of the different As chemical species may largely vary among individuals, which may have resulted in the large variation in As ratios. A speciation analysis of As is essential to assess the characterisation of its transplacental behaviour and developmental effects [13]. Sb cord blood to maternal blood ratios exceeding 1 were observed in $71 \%$ of the participants. Because the $\mathrm{Sb}$ concentrations were at low levels in the cord blood and maternal blood, the large variation of the $\mathrm{Sb}$ ratio might include the uncertainty of the analytical values (limitation). However, the Sb cord blood to maternal blood ratio was 2.0, and this level of exposure to $\mathrm{Sb}$ would be problematic for foetuses from a health perspective.

Moreover, cord blood to maternal blood Cd ratios $>1$ were observed in $39 \%$ of the participants, with large variation among individuals. Genetic variation leading to differences in expression and regulation of metallothionein proteins may have contributed to the differences observed among participants in terms of $\mathrm{Cd}$ uptake and metabolism [75]. Further research should focus on genetic variation analyses such as single nucleotide polymorphisms (SNPs) to identify vulnerable sections of the population.

There are some limitations of our research. Firstly, there was time-lag between sampling of the maternal blood and cord blood in the urban area of our cohort. Copper, zinc and selenium are essential trace elements of which blood concentrations are maintained in certain ranges. Estimated daily dietary intakes of total zinc were $8.8-14.4 \mathrm{mg} /$ day for adults aged 20 50 years [76]. The average daily intake of copper was about $1 \mathrm{mg}$ with the primary source being the diet [77]. We could assume that blood trace element concentrations were in steady states since they were taken daily via diet. Actually, Willett reported that observed intra-class correlations (ICC) in 3-month intervals were 0.76 for serum selenium and 0.95 for whole blood selenium. This suggests that whole blood selenium concentration is less susceptible to temporal variation and thus a better index of long-term intake compared to the serum selenium concentration [78]. Lee at al. reported that whole blood ICC for $\mathrm{Pb}, \mathrm{Hg}$ and $\mathrm{Cd}$ was $0.81,0.71$ and 0.83 , respectively [79]. We could not find about blood ICC of other elements. We might be able to confirm the effect of sampling time-lag on the cord/maternal blood ratio using the sample of coastal area in our cohort because sampling of the maternal blood (1 day postpartum) in the coastal area was almost same with the cord blood (at birth). Secondly, in case some element concentrations were extremely of low levels in the cord blood and maternal blood, the large variation of the ratio might include the uncertainty of the analytical values. Thirdly, we had not performed arsenic speciation yet. We would conduct further research about arsenic speciation in the future using a sample of our cohort. Lastly, this study has certain limitations because we do not have data regarding genetic background, such as SNPs and DNA methylation. A noticeable limitation is we could not reveal the effects of a genetic factor on the large variations in the ratio between individuals.

\section{Conclusions}

$\mathrm{Sb}$ was detected in $72 \%$ of the cord blood samples, whereas $\mathrm{Sn}$ was detected in $44 \%$ of the maternal blood samples. By contrast, Bi was detected in $7 \%$ of the maternal blood samples. Sn was detected in $36 \%$ of the cord blood samples, whereas Bi was detected in $18 \%$ of the cord blood samples. Concentrations of $\mathrm{Zn}, \mathrm{Cu}, \mathrm{Pb}$, $\mathrm{Cd}$ and $\mathrm{As}$ in the maternal blood were significantly higher than their concentration levels in the cord blood. In contrast, $\mathrm{THg}, \mathrm{MeHg}$ and $\mathrm{Sb}$ levels in the cord blood were approximately two times higher than their levels in the maternal blood. Foetal exposure to elements with large variations in the cord blood to maternal blood ratios ( $\mathrm{IHg}, \mathrm{As}, \mathrm{Cd}$ and $\mathrm{Sb}$ ) should be evaluated using the cord blood samples, especially because the placental transfer of these elements varies largely among individuals. In the future, our results will be useful to evaluate the exposure levels of these elements and to investigate the associations between toxic element exposure and children's health [80]. 


\section{Additional file}

Additional file 1: Table S1. Results from analytical quality control of toxic and trace elements in the whole blood. Table S2. Results from external quality control and other analytical reference values of toxic and trace elements in the whole blood. Table S3. Spearman's rank correlation coefficients (rho) for five elements in the maternal blood, cord blood and placenta. Figure S1. Flow chart of the study participants. Figure S2. Correlations of blood mercury concentrations between A laboratory (International mercury lab) and B laboratory (IDEA consultant). $N=5$, Pearson product-moment correlation coefficient ( $r$ ). A (total mercury in the whole blood): $Y=0.96 x-0.99, B$ (methylmercury in the whole blood): $Y=0.97 x-1.1, C$ (total mercury in red blood cells): $Y=0.84 x+$ $0.48, \mathrm{D}$ (methylmercury in red blood cells): $Y=0.82 x-0.83, \mathrm{E}$ (total mercury in plasma): $Y=0.77 x+0.21, F$ (methylmercury in plasma): $Y=0.65 x+$ 0.08. (PDF $275 \mathrm{~kb})$

\section{Abbreviations}

ADHD: Attention-deficit/hyperactivity disorder; As: Arsenic; Bi: Bismuth; Cd: Cadmium; Cu: Copper; CVAAS: Cold vapour atomic absorption spectrometry; GC-ECD: Gas chromatography with electron capture detection; Hg: Mercury; ICC: Intra-class correlations; ICP-MS: Inductively coupled plasma mass spectrometry; IHg: Inorganic mercury; LOD: Limit of detection; MeHg: Methylmercury; Pb: Lead; RSD: Relative standard deviation; Sb: Antimony; Se: Selenium; Sn: Tin; SNPs: Single nucleotide polymorphisms; THg: Total mercury; TSCD: Tohoku Study of Child Development; Zn: Zinc

\section{Acknowledgements}

We thank all the families that participated in the cohort study. We would like to acknowledge the contributions of the staff at the time of Environmental Health Sciences, Tohoku University Graduate School of Medicine. We would especially like to thank them for helping us to organise and collect data for the cohort study.

\section{Funding}

This research was funded by the Japan Ministry of Health, Labour and Welfare and the Ministry of the Environment, Japan. No funding numbers are available. The findings and conclusions of this article are solely the responsibility of the authors and do not represent the official views of the above government.

\section{Availability of data and materials}

Sharing the raw research data publicly is not possible because data privacy could be compromised. Data are unsuitable for public deposition because of ethical restrictions and the legal framework of Japan. It is prohibited by the Act on the Protection of Personal Information (Act No. 57 of 30 May 2003, amendment on 9 September 2015) to publicly deposit the data containing personal information. Ethical Guidelines for Medical and Health Research Involving Human Subjects enforced by the Japan Ministry of Education, Culture, Sports, Science and Technology and the Ministry of Health, Labour and Welfare also restrict the open sharing of the epidemiologic data. However, the raw data are available through the corresponding author and any researcher interested in access to the raw data can make the appropriate request to the corresponding author and colleagues.

\section{Authors' contributions}

NT, KN, NK and HS designed and conducted the survey. Ml performed the mercury analysis, data confirmation of elemental analysis, statistical analysis and interpretation of the results and drafted the manuscript. SK, KY, SF and HS critically reviewed the manuscript. All authors read and approved the final version of the manuscript as submitted.

\section{Ethics approval and consent to participate}

All the procedures of this study were approved by the Medical Ethics Committee of the Tohoku University Graduate School of Medicine and of the National Institute for Environmental Studies. All the participants provided written informed consent.

\section{Consent for publication}

Not applicable.

\section{Competing interests}

The authors declare that they have no competing interests.

\section{Publisher's Note}

Springer Nature remains neutral with regard to jurisdictional claims in published maps and institutional affiliations.

\section{Author details}

${ }^{1}$ Centre for Health and Environmental Risk Research, National Institute for Environmental Studies, Tsukuba, Ibaraki, Japan. ²Department of Nutrition, College of Nutrition, Koshien University, Takarazuka, Hyogo, Japan. ${ }^{3}$ Department of Development and Environmental Medicine, Tohoku University Graduate School of Medicine, Sendai, Miyagi, Japan. ${ }^{4}$ Department of Human Health and Nutrition, Faculty of Comprehensive Human Sciences, Shokei Gakuin University, Sendai, Miyagi, Japan. ${ }^{5}$ Miyagi University of Education, Sendai, Miyagi, Japan. ${ }^{6}$ Tohoku University, Sendai, Miyagi, Japan.

Received: 21 November 2018 Accepted: 11 April 2019

Published online: 17 May 2019

\section{References}

1. ATSDR. The ATSDR (Agency for Toxic Substances and Disease Registry Division of Toxicology and Human Health Sciences) 2015 Substance priority list. Atlanta. 2015. https://www.atsdr.cdc.gov/spl/. Accessed 22 Apr 2019.

2. NRC, National Research Council. Toxicological effects of methylmercury. Washington, DC: National Academy Press; 2000.

3. Lyall K, Schmidt RJ, Hertz-Picciotto I. Maternal lifestyle and environmental risk factors for autism spectrum disorders. Int J Epidemiol. 2014;43(2):443-64.

4. Grandjean P, Weihe P, White RF, Debes F, Araki S, Yokoyama K, et al. Cognitive deficit in 7-year-old children with prenatal exposure to methylmercury. Neurotoxicol Teratol. 1997;19(6):417-28.

5. Myers GJ, Davidson PW, Cox C, Shamlaye CF, Palumbo D, Cernichiari E, et al. Prenatal methylmercury exposure from ocean fish consumption in the Seychelles child development study. Lancet. 2003;361(9370):1686-92.

6. Guan H, Piao F-Y, Li X-W, Li Q-J, Xu L, Yokoyama K. Maternal and fetal exposure to four carcinogenic environmental metals. Biomed Environ Sci. 2010;23(6):458-65.

7. Bellinger DC. Teratogen update: lead and pregnancy. Birth Defects Res A Clin Mol Teratol. 2005;73(6):409-20.

8. Dzwilewski KL, Schantz SL. Prenatal chemical exposures and child language development. J Commun Disord. 2015:57:41-65.

9. Pocock SJ, Smith M, Baghurst P. Environmental lead and children's intelligence: a systematic review of the epidemiological evidence. BMJ (Clinical research ed). 1994;309(6963):1189-97.

10. Hong SB, Im MH, Kim JW, Park EJ, Shin MS, Kim BN, et al. Environmental lead exposure and attention deficit/hyperactivity disorder symptom domains in a community sample of south Korean school-age children. Environ Health Perspect. 2015;123(3):271-6.

11. Tekin D, Kayaalti Z, Aliyev V, Soylemezoglu T. The effects of metallothionein $2 \mathrm{~A}$ polymorphism on placental cadmium accumulation: is metallothionein a modifiying factor in transfer of micronutrients to the fetus? J Appl Toxicol. 2012;32(4):270-5.

12. Salpietro CD, Gangemi S, Minciuollo PL, Briuglia S, Merlino MV, Stelitano A et al. Cadmium concentration in maternal and cord blood and infant birth weight: a study on healthy non-smoking women. J Perinat Med. 2002;30(5): 395-9.

13. Gilbert-Diamond D, Emond JA, Baker ER, Korrick SA, Karagas MR. Relation between in utero arsenic exposure and birth outcomes in a cohort of mothers and their newborns from New Hampshire. Environ Health Perspect. 2016;124(8):1299-307.

14. Vahter M. Health effects of early life exposure to arsenic. Basic Clin Pharmacol Toxicol. 2008;102(2):204-11.

15. Smith AH, Marshall G, Yuan Y, Ferreccio C, Liaw J, von Ehrenstein O, et al. Increased mortality from lung cancer and bronchiectasis in young adults after exposure to arsenic in utero and in early childhood. Environ Health Perspect. 2006;114(8):1293-6.

16. Liaw J, Marshall G, Yuan Y, Ferreccio C, Steinmaus C, Smith AH. Increased childhood liver cancer mortality and arsenic in drinking water in northern Chile. Cancer Epidemiol Biomark Prev. 2008;17(8):1982-7.

17. Chan S, Gerson B, Subramaniam S. The role of copper, molybdenum, selenium, and zinc in nutrition and health. Clin Lab Med. 1998;18(4):673-85. 
18. Burguera M, Burguera JL, Rondon C, Garcia MI, de Pena YP, Villasmil LM. Determination of bismuth in biological tissues by electrothermal atomic absorption spectrometry using platinum and tartaric acid as chemical modifier. J Anal At Spectrom. 2001;16(10):1190-5.

19. Dolara P. Occurrence, exposure, effects, recommended intake and possible dietary use of selected trace compounds (aluminium, bismuth, cobalt, gold, lithium, nickel, silver). Int J Food Sci Nutr. 2014;65(8):911-24.

20. Sundar S, Chakravarty J. Antimony toxicity. Int J Environ Res Public Health. 2010;7(12):4267

21. Volonakis G, Filip MR, Haghighirad AA, Sakai N, Wenger B, Snaith HJ, et al. Lead-free halide double perovskites via heterovalent substitution of noble metals. J Phys Chem Lett. 2016;7(7):1254-9.

22. Gardella C. Lead exposure in pregnancy: a review of the literature and argument for routine prenatal screening. Obstet Gynecol Surv. 2001;56(4):231-8.

23. Schoeters $G$, Den Hond $E$, Zuurbier M, Naginiene $R$, van den Hazel $P$, Stilianakis N, et al. Cadmium and children: exposure and health effects. Acta Paediatr Suppl. 2006;95(453):50-4.

24. Holmes P, James KA, Levy LS. Is low-level environmental mercury exposure of concern to human health? Sci Total Environ. 2009;408(2):171-82.

25. Reis MF, Sampaio C, Brantes A, Aniceto P, Melim M, Cardoso L, et al. Human exposure to heavy metals in the vicinity of Portuguese solid waste incinerators--part 2: biomonitoring of lead in maternal and umbilical cord blood. Int J Hyg Environ Health. 2007;210(3-4):447-54.

26. Rollin HB, Rudge CVC, Thomassen Y, Mathee A, Odland JO. Levels of toxic and essential metals in maternal and umbilical cord blood from selected areas of South Africa-results of a pilot study. J Environ Monit. 2009;11(3):618-27.

27. Jones EA, Wright JM, Rice G, Buckley BT, Magsumbol MS, Barr DB, et al. Metal exposures in an inner-city neonatal population. Environ Int. 2010; 36(7):649-54.

28. Nakai K, Suzuki K, Oka T, Murata K, Sakamoto M, Okamura K, et al. The Tohoku study of child development: a cohort study of effects of perinatal exposures to methylmercury and environmentally persistent organic pollutants on neurobehavioral development in Japanese children. Tohoku J Exp Med. 2004;202(3):227-37.

29. Tatsuta N, Kurokawa N, Nakai K, Suzuki K, Iwai-Shimada M, Murata K, et al. Effects of intrauterine exposures to polychlorinated biphenyls, methylmercury, and lead on birth weight in Japanese male and female newborns. Environ Health Prev Med. 2017;22(1):39.

30. Suzuki K, Nakai K, Sugawara T, Nakamura T, Ohba T, Shimada M, et al. Neurobehavioral effects of prenatal exposure to methylmercury and PCBs, and seafood intake: neonatal behavioral assessment scale results of Tohoku study of child development. Environ Res. 2010;110(7):699-704.

31. Tatsuta N, Nakai K, Suzuki K, Kurokawa N, Shimada M, Yaginuma K, et al. Construction of maladaptive behavior scale [in Japanese]. Jap J Hyg. 2010; 65(4):516-23.

32. Tatsuta N, Nakai K, Murata K, Suzuki K, Iwai-Shimada M, Yaginuma-Sakurai K, et al. Prenatal exposures to environmental chemicals and birth order as risk factors for child behavior problems. Environ Res. 2012;114:47-52.

33. Acharya G, Sonesson SE, Flo K, Räsänen J, Odibo A. Hemodynamic aspects of normal human feto-placental (umbilical) circulation. Acta Obstet Gynecol Scand. 2016;95(6):672-82. https://doi.org/10.1111/aogs.12919.

34. Ministry of the Environment J. Mercury analysis manual. Tokyo: Ministry of the Environment, Japan; 2004.

35. Iwai-Shimada M, Satoh H, Nakai K, Tatsuta N, Murata K, Akagi H. Methylmercury in the breast milk of Japanese mothers and lactational exposure of their infants. Chemosphere. 2015;126:67-72.

36. Akagi H, Castillo ES, Corles-Maramba N, Francisco-Rivera AT, Timbang TD. Health assessment for mercury exposure among schoolchildren residing near a gold processing and refining plant in Apokon, Tagum, Davao del Norte. Philippines Sci Total Environ. 2000;259(1-3):31-43.

37. Currie LA. Detection and quantification limits: origins and historical overview. Anal Chim Acta. 1999:391(2):127-34.

38. Murata K, Dakeishi M, Shimada M, Satoh H. Assessment of intrauterine methylmercury exposure affecting child development: messages from the newborn. Tohoku J Exp Med. 2007;213(3):187-202.

39. Caserta D, Graziano A, Lo Monte G, Bordi G, Moscarini M. Heavy metals and placental fetal-maternal barrier: a mini-review on the major concerns. Eur Rev Med Pharmacol Sci. 2013;17(16):2198-206.

40. Goyer RA. Transplacental transfer of lead and cadmium. In: Goyer RA, Cherian MG, editors. Toxicology of metals: biochemical aspects. Berlin, Heidelberg: Springer Berlin Heidelberg; 1995. p. 1-17.
41. Aschner M, Aschner JL. Mercury neurotoxicity: mechanisms of blood-brain barrier transport. Neurosci Biobehav Rev. 1990;14(2):169-76.

42. Sakamoto M, Chan HM, Domingo JL, Koriyama C, Murata K. Placental transfer and levels of mercury, selenium, vitamin E, and docosahexaenoic acid in maternal and umbilical cord blood. Environ Int. 2018;111:309-15.

43. Sakamoto M, Murata K, Kubota M, Nakai K, Satoh H. Mercury and heavy metal profiles of maternal and umbilical cord RBCs in Japanese population. Ecotoxicol Environ Saf. 2010;73(1):1-6.

44. Stern AH, Smith AE. An assessment of the cord blood:maternal blood methylmercury ratio: implications for risk assessment. Environ Health Perspect. 2003;111(12):1465-70.

45. WHO. Methylmercury. Geneva: World Health Organization; 1990.

46. Nordberg M, Nordberg GF. Toxicological aspects of metallothionein. Cell Mol Biol. 2000;46(2):451-63.

47. Espart A, Artime S, Tort-Nasarre G, Yara-Varon E. Cadmium exposure during pregnancy and lactation: materno-fetal and newborn repercussions of $\mathrm{Cd}$ (ii), and Cd-metallothionein complexes. Metallomics. 2018;10(10):1359-67.

48. Goyer RA, Cherian MG. Role of metallothionein in human placenta and rats exposed to cadmium. IARC Sci Publ. 1992;118:239-47.

49. Gebel T, Claussen K, Dunkelberg H. Human biomonitoring of antimony. Int Arch Occup Environ Health. 1998;71(3):221-4.

50. Hinwood AL, Stasinska A, Callan AC, Heyworth J, Ramalingam M, Boyce M, et al. Maternal exposure to alkali, alkali earth, transition and other metals: concentrations and predictors of exposure. Environ Pollut. 2015;204:256-63.

51. Fonturbel FE, Barbieri E, Herbas C, Barbieri FL, Gardon J. Indoor metallic pollution related to mining activity in the Bolivian Altiplano. Environ Pollut. 2011;159(10):2870-5.

52. Goix S, Point D, Oliva P, Polve M, Duprey $J$, Mazurek $H$, et al. Influence of source distribution and geochemical composition of aerosols on children exposure in the large polymetallic mining region of the Bolivian Altiplano. Sci Total Environ. 2011;412-413:170-84.

53. Yoshinaga J, Yamasaki K, Yonemura A, Ishibashi Y, Kaido T, Mizuno K, et al. Lead and other elements in house dust of Japanese residences-source of lead and health risks due to metal exposure. Environ Pollut. 2014;189:223-8.

54. Akerstrom M, Barregard L, Lundh T, Sallsten G. The relationship between cadmium in kidney and cadmium in urine and blood in an environmentally exposed population. Toxicol Appl Pharmacol. 2013;268(3):286-93.

55. WHO. Cadmium. Geneva: World Health Organization; 1992.

56. Baranowska I. Lead and cadmium in human placentas and maternal and neonatal blood (in a heavily polluted area) measured by graphite furnace atomic absorption spectrometry. Occup Environ Med. 1995;52(4):229-32.

57. Tsuchiya H, Mitani K, Kodama K, Nakata T. Placental transfer of heavy metals in normal pregnant Japanese women. Arch Environ Health. 1984;39(1):11-7.

58. Al-Saleh I, Shinwari N, Mashhour A, Rabah A. Birth outcome measures and maternal exposure to heavy metals (lead, cadmium and mercury) in Saudi Arabian population. Int J Hyg Environ Health. 2014:217(2-3):205-18.

59. García-Esquinas E, Pérez-Gómez B, Fernández-Navarro P, Fernández MA, de Paz C, Pérez-Meixeira AM, et al. Lead, mercury and cadmium in umbilical cord blood and its association with parental epidemiological variables and birth factors. BMC Public Health. 2013;13(1):841.

60. Esteban-Vasallo MD, Aragones N, Pollan M, Lopez-Abente G, Perez-Gomez B. Mercury, cadmium, and lead levels in human placenta: a systematic review. Environ Health Perspect. 2012;120(10):1369-77.

61. CDC. Fourth National Report on Human Exposure to Environmental Chemicals: Centers for Disease Control and Prevention, USA. 2017. https:// www.cdc.gov/exposurereport/pdf/FourthReport_UpdatedTables_Volume1_ Jan2017.pdf. Accessed 22 Apr 2019.

62. Thomas S, Arbuckle TE, Fisher M, Fraser WD, Ettinger A, King W. Metals exposure and risk of small-for-gestational age birth in a Canadian birth cohort: the MIREC study. Environ Res. 2015;140:430-9.

63. Huang SH, Weng KP, Lin CC, Wang CC, Lee CT, Ger LP, et al. Maternal and umbilical cord blood levels of mercury, manganese, iron, and copper in southern Taiwan: a cross-sectional study. J Chin Med Assoc. 2017:80(7):442-51.

64. Li S, Xu J, Liu Z, Yan CH. The non-linear association between low-level lead exposure and maternal stress among pregnant women. Neurotoxicology. 2017;59:191-6.

65. Adams JB, Audhya T, McDonough-Means S, Rubin RA, Quig D, Geis E, et al. Toxicological status of children with autism vs. neurotypical children and the association with autism severity. Biol Trace Elem Res. 2013;151(2):171-80. 
66. Tsuji JS, Garry MR, Perez V, Chang ET. Low-level arsenic exposure and developmental neurotoxicity in children: a systematic review and risk assessment. Toxicology. 2015;337:91-107.

67. Parajuli RP, Umezaki M, Fujiwara T, Watanabe C. Association of cord blood levels of lead, arsenic, and zinc and home environment with children neurodevelopment at 36 months living in Chitwan Valley, Nepal. PLoS One. 2015;10(3):e0120992.

68. Meltzer HM, Maage A, Ydersbond TA, Haug E, Glattre E, Holm H. Fish arsenic may influence human blood arsenic, selenium, and T4:T3 ratio. Biol Trace Elem Res. 2002;90(1-3):83-98.

69. Sakurai T, Kojima C, Ochiai M, Ohta T, Fujiwara K. Evaluation of in vivo acute immunotoxicity of a major organic arsenic compound arsenobetaine in seafood. Int Immunopharmacol. 2004;4(2):179-84.

70. NRC. Arsenic in drinking water. Washington, DC: National Research Council; 1999.

71. Hughes MF. Biomarkers of exposure: a case study with inorganic arsenic Environ Health Perspect. 2006;114(11):1790-6.

72. Lavolpe M, Greco LL, Kesselman D, Rodriguez E. Differential toxicity of copper, zinc, and lead during the embryonic development of Chasmagnathus granulatus (Brachyura, Varunidae). Environ Toxicol Chem. 2004;23(4):960-7.

73. Simons TJ. Cellular interactions between lead and calcium. Br Med Bull. 1986;42(4):431-4.

74. Ettinger AS, Hu H, Hernandez-Avila M. Dietary calcium supplementation to lower blood lead levels in pregnancy and lactation. J Nutr Biochem. 2007; 18(3):172-8.

75. McElroy JA, Bryda EC, McKay SD, Schnabel RD, Taylor JF. Genetic variation at a metallothionein $2 \mathrm{~A}$ promoter single-nucleotide polymorphism in white and black females in Midwestern United States. J Toxicol Environ Health A. 2010;73(19):1283-7.

76. WHO. Zinc. World Health Organization, Environmental Health Criteria 221, 2001.

77. Donald GB. Copper. J Toxicol Clin Toxicol. 1999:2:217-30.

78. Willett W. Nutritional epidemiology. Oxford University Press, 2012.

79. Lee S, Shin M, Hong YC, Kim JH. Temporal variability of blood lead, mercury, and cadmium levels in elderly panel study (2008-2014). Int J Hyg Environ Health. 2017;220:407-14

80. Nomura K, Karita K, Araki A, Nishioka E, Muto G, Iwai-Shimada M, et al. For making a declaration of countermeasures against the falling birth rate from the Japanese Society for Hygiene: summary of discussion in the working group on academic research strategy against an aging society with low birth rate. Environ Health Prev Med. 2019;24(1):14.

Ready to submit your research? Choose BMC and benefit from:

- fast, convenient online submission

- thorough peer review by experienced researchers in your field

- rapid publication on acceptance

- support for research data, including large and complex data types

- gold Open Access which fosters wider collaboration and increased citations

- maximum visibility for your research: over $100 \mathrm{M}$ website views per year

At BMC, research is always in progress.

Learn more biomedcentral.com/submissions 